\title{
INDUKSI PERKECAMBAHAN PADA BIJI KARET (Hevea brasiliensis Muell) DENGAN SISTEM PERENDAMAN DAN TANPA PERENDAMAN AIR
}

\section{Kamsia Dorliana Sitanggang, Khairul Rizal, Syafril Fadli Tanjung}

Prodi Agroteknologi, Fakultas Sains dan Teknologi Universitas Labuhanbatu

Email : kamsiasitanggang@gmail.com

\begin{abstract}
This study aims to see the differences in the speed of sprout growth with immersion systems and without water immersion. The results showed that there were differences percentage of seeds germinated between seeds that were given water immersion for 12 hours $(85 \%)$ and were not given water immersion (65\%). For the other parameter average days of sprouting, where the seeds that are given water immersion are more quickly induced by sprouts as much as $60 \%$ age 7 days after seedling, compared not given water immersion can only be induced by $40 \%$. Likewise, the 17th day after the seedlings were induced by 85\% for soaking seeds and 65\% for seeds that were not soaking.
\end{abstract}

Keywords: Rubber, Sprout, Water immersion

\section{PENDAHULUAN}

Tanaman karet merupakan salah satu tanaman perkebunan yang memiliki ukuran batang yang besar dan tinggi. Tanaman karet menghasilkan getah (lateks) yang dapat diolah menjadi bahan baku industri karet. Tanaman karet menghasilkan biji yang berukuran besar dan memiliki kulit atau cangkang yang keras dengan ketebalan kulit sekitar (4,2 mm). Biji karet biasanya ditumbuhkan dan digunkan sebagai sumber batang bawah (Setiawan \& Andoko, 2000).

Biji yang memiliki kualitas yang baik berasal dari pohon yang telah berumur 15 hingga 25 tahun, karena pada umur tersebut pohon akan menghasilkan biji yang memiliki viabilitas yang tinggi (Sianturi, 2001). Penggunaan biji sebagai batang bawah sering mengalami hambatan karena kulit biji yang keras dan tebal, sehingga membutuhkan waktu 21 hari untuk berkecambah. Salah satu teknik untuk mempercepat perkecambahan yaitu dengan cara merendam biji kedalam air (Ance \& Karta, 1986). Perendaman biji karet kedalam air bertujuan untuk memudahkan penyerapan air oleh benih, sehingga kulit benih menjadi lisis dan lemah (Zainal et al., 2016).

Tipe perkecambahan benih karet adalah hypogeal, dimana munculnya radikula diikuti dengan pemanjangan plumula. Hipokotil tidak memanjang keatas permukaan tanah sedangkan kotiledon tetap berada di dalam kulit biji dibawah permukaan tanah (Sutopo, 2002). Biji karet juga tergolong rekalsitran (viabilitas biji yang cepat menurun) dan tidak tahan terhadap kekeringan (akan mati bila kadar 
air dibawah 12\%) serta tidak mempunyai masa dormansi (Indraty, 2010). Penelitian ini bertujuan untuk melihat perbedaan kecepatan petumbuhan kecambah dengan sistem perendaman dan tanpa perendaman air.

\section{METODE PENELITIAN}

\section{Tempat dan Waktu Penelitian}

Penelitian ini dilaksanakan di lahan percobaan STIPER Labuhanbatu pada bulan Januari sampai bulan Juni 2017.

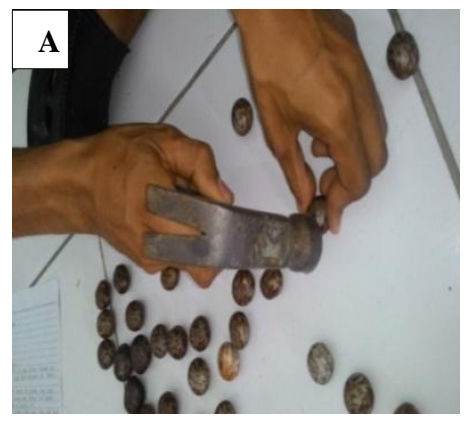

\section{Seleksi Biji}

Biji karet yang digunakan sebagai bahan penelitian adalah biji karet segar yang berasal dari pohon berumur 15 hingga 25 tahun. Penilaian kesegaran ditentukan atas dasar warna belahan biji putih murni sampai kekuningan.

\section{Melukai Kulit Biji Secara Mekanis}

Perusakan kulit biji dilakukan untuk memudahkan proses penyerapan air sehingga mempercepat pertumbuhan kecambah (Gambar 1).

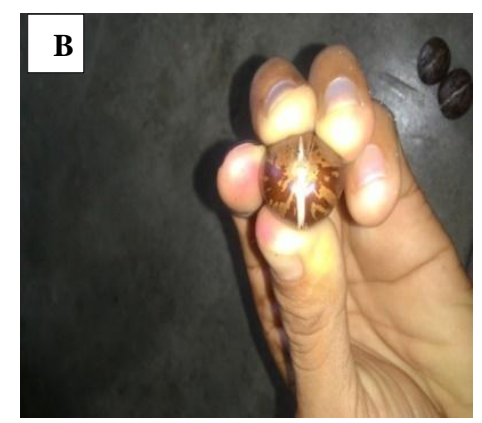

Gambar 1: A. Peretakan kulit biji; B. Biji karet yang sudah dilakukan peretakan kulitnya

\section{Perendaman Biji}

Perendaman biji karet dilakukan didalam stoples yang berisi air. Perendaman dilakukan selama 12 jam.

\section{Persemaian Biji}

Proses persemaian biji karet memerlukan 6 buah baki, dimana 3 buah baki untuk perlakuan biji tanpa perendaman air dan 3 buah baki untuk perlakuan biji dengan sistem perendaman air. Setiap baki diisi pasir sebagai media persemaian, kemudian diletakkan biji yang telah dilukai kulitnya sebanyak 20 biji. Untuk menjaga kelembaban media, maka dilakukan penyiraman sebanyak dua kali sehari pada pagi dan sore.

\section{HASIL DAN PEMBAHASAN}

\section{Persentasi Perkecambahan Biji Karet}

Persentase perkecambahan pada biji karet yang diberi perendaman air dan tanpa diberi perendaman air selama 12 jam menunjukkan persentase perkecambahan yang berbeda (Gambar 1). Perbedaan tersebut dapat dilihat pada jumlah biji karet yang berkecambah, dimana biji karet yang mengalami perkecambahan lebih banyak pada biji yang direndam air $(85 \%)$ dibanding tanpa diberi perendaman $(65 \%)$. Salah satu faktor penyebab terjadinya perbedaan persentase perkecambahan diduga karena terdapat beberapa biji yang digunakan 
sebagai bahan percobaan memiliki umur yang lebih dari 40 hari. Damanik et al. (2010) mengatakan bahwa pengumpulan biji karet yang akan digunakan sebagai bibit sebaiknya tidak lebih dari 40 hari setelah jatuh.
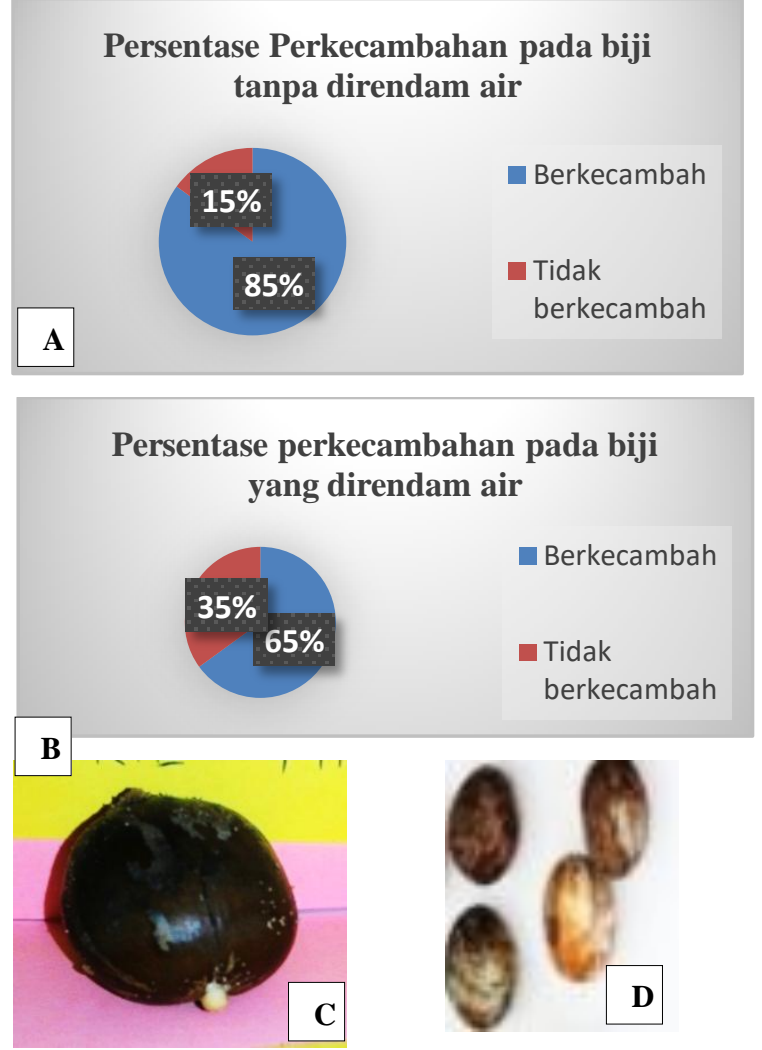

Gambar 2. (A)Persentasi pertumbuhan kecambah karet umur 17 HST pada biji yang direndam air selama 12 jam; (B) Persentasi pertumbuhan kecambah karet umur 17 HST pada biji tanpa diberi perendaman air; (C) biji yang tumbuh kecambah; (D) tidak tumbuh kecambah

\section{Rata-Rata Hari Tumbuh Kecambah (\%)}

Biji karet membutuhkan waktu selama 21 hari untuk berkecambah, dan apabila tidak segera ditanam akan terjadi penurunan daya tumbuh. Biji karet yang diberikan perendaman air akan mengalami pertumbuhan kecambah yang lebih cepat dibandingkan biji karet yang tanpa direndam air. Pada biji yang dilakukan perendaman air, kecambah sudah muncul $60 \%$ pada umur 7 hari setelah semai, sedangkan pada biji yang tidak direndam air kecambah baru muncul $40 \%$ pada umur 7 hari setelah semai (Tabel 1).

Tabel 1. Persentase pertumbuhan kecambah pada biji perendaman dan tanpa perendaman air

\section{Pertumbuhan \\ Hari ke-}

\begin{tabular}{lrrrrrrrrr}
\cline { 2 - 9 } kecambah (\%) & $\mathbf{1}$ & $\mathbf{3}$ & $\mathbf{5}$ & $\mathbf{7}$ & $\mathbf{9}$ & $\mathbf{1 1}$ & $\mathbf{1 3}$ & $\mathbf{1 5}$ & $\mathbf{1 7}$ \\
\hline Direndam air & 0 & 3 & 13 & 60 & 72 & 78 & 82 & 82 & 85 \\
Tanpa air & 0 & 2 & 17 & 40 & 48 & 57 & 63 & 65 & 65 \\
\hline
\end{tabular}


Dari pengamatan Tabel 1 diatas dapat dilihat bahwa pada hari pertama setelah semai belum ditemukan adanya biji karet yang berkecambah baik pada biji karet yang diberikan perendaman air maupun biji karet yang tidak diberikan perendaman air. Pada hari ke-7 setelah semai sudah ditemukan biji karet yang mulai tumbuh sekitar $60 \%$ pada biji yang diberi perendaman air dan $40 \%$ pada biji yang tidak diberikan perendaman air (Gambar 3). Kecambah yang tumbuh pada biji yang diberikan perendaman air lebih cepat terdinduksi tanpa diberikan perendaman air, hal tersebut dikarenakan biji yang diberikan

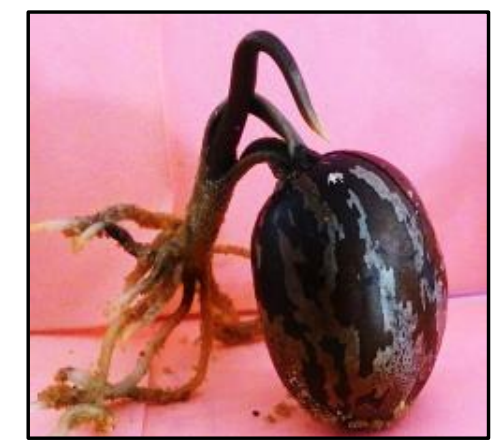

Gambar 3. Perkecambahan biji karet

\section{KESIMPULAN}

Perendaman biji karet dengan menggunakan air selama 12 jam mampu menginduksi perkecambahan lebih cepat pada umur 7 hari setelah semai, dimana biji yang berkecambah sebanyak $60 \%$ pada biji yang diberi perendaman air sedangkan biji yang tidak diberi perendaman air hanya mampu terinduksi sebesar 40\%. Demikian juga hari ke-17 stelah semai dimana biji yang terinduksi sebesar $85 \%$ untuk biji yang diberi perendaman dan $65 \%$ untuk biji yang tidak diberi perendaman. perlakuan perendaman memiliki kadar air yang lebih tinggi, dibandingkan biji yang tanpa direndam air sehingga dapat menyebabkan terjadinya pembengkakan pada kotiledon dan menjadikan pecahnya testa (Anwar, 2006). Air yang direndam selama 12 jam telah mencapai maksimum atau mencapai imbibisi yang optimum sehingga air dapat masuk kedalam biji karena biji telah mengalami perekahan kulit sehingga air dan oksigen dapat masuk kedalam biji (Sutopo, 2002). Peningkatan kadar air ini diakibatkan adanya proses perendaman sehingga biji akan memiliki kadar air antara 40-60\% (Sutopo, 2002).

\section{DAFTAR PUSTAKA}

Ance, G., Karta, S. 1986. Teknologi Benih. Jakarta(ID): Rineka Cipta.

Anwar, C. 2006. Manajemen dan Teknologi Budidaya Karet. Medan (ID): Pusat Penelitian Karet Sei Putih.

Damanik, S., Syakir, M., Siswanto. 2010. Budidaya dan Pasca Panen Karet. Bogor (ID):Pusat Penelitian dan Pengembangan Perkebunan.

Indraty, I.S. 2010. Mengenal Teknologi Baru untuk Pengembangan Hutan Karet. Salatiga (ID): Balai Penelitian Getas Hal: 12-14.

Setiawan, D.H., Andoko A. 2000. Petunjuk Lengkap Budidaya Karet. Jakarta (ID): Agromedia Pustaka.

Sianturi, H.S.D. 2001. Budidaya Tanaman Karet. Medan (ID): Universitas Sumatera Utara Press. 
Sutopo, L. 2002. Teknologi Benih (edisi revisi). Jakarta (ID):Fakultas Pertanian Univ Brawijaya. PT Raja Grafindo Persada.

Zainal, B., Syarifah, Hidayat. 2016. Pengaruh Perlakuan Perendaman Air Panas dan Air Dingin Terhadap Perkecambahan Benih Karet (Hevea brasilliensis muell.Arg) dan Sumbangsihnya pada Mata Pelajaran Biologi Materi Pertumbuhan Tumbuhan Kelas Xii SMA / MA. Jurnal Bioilmi. Palembang (ID): Vol. 2 No. 2 Agustu2016 | 103. 